\title{
Community of orchid bees (Hymenoptera: Apidae) in transitional vegetation between Cerrado and Atlantic Forest in southeastern Brazil
}

\author{
Pires, EP. ${ }^{a}$, Morgado, $L N .^{a}$, Souza, B. ${ }^{a}$, Carvalho, $C F^{a}{ }^{a}$ and Nemésio, $A .^{b *}$ \\ ${ }^{a}$ Departamento de Entomologia, Universidade Federal de Lavras, CP 3037, CEP 37200-000, Lavras, MG, Brazil \\ ${ }^{b}$ Instituto de Biologia, Universidade Federal de Uberlândia, Rua Ceará S/N, Umuarama, CEP 38400-902, Uberlândia, \\ $M G$, Brazil \\ *e-mail: andre.nemesio@gmail.com
}

Received June 4, 2012 - Accepted September 10, 2012 - Distributed August 31, 2013

(With 1 figure)

\begin{abstract}
The community of orchid bees (Hymenoptera: Apidae: Euglossina) was studied at an area in the transition between the Cerrado and Atlantic Forest biomes, from March, 2010 to February, 2011 in the Barroso region, state of Minas Gerais, eastern Brazil. Orchid-bee males were collected with bait traps containing three different scents (cineole, eugenol and vanillin) and with entomological nets for collecting bees on flowers. A total of 614 orchid-bee males were collected using aromatic traps, belonging to four genera and 15 species. Twenty-five female specimens belonging to two genera and at least three species were collected on flowers. Eulaema (Apeulaema) nigrita Lepeletier, 1841 was the most abundant species (50\% of collected specimens), followed by Euglossa (Euglossa) truncata Rebêlo \& Moure, 1996 (28\%). Cineole was the most attractive compound ( $66.5 \%$ of males and 13 species), followed by eugenol (16\% and 9 species) and vanillin (13.5\% and 4 species). Eulaema (Apeulaema) marcii Nemésio, 2009 and Eufriesea auriceps (Friese, 1899) were attracted to all scents, whereas Euglossa species were collected only in cineole and eugenol.
\end{abstract}

Keywords: Apoidea, Atlantic Forest, Cerrado, Hexapoda, Inventory.

\section{Comunidade de Euglossina (Hymenoptera: Apidae) em área de transição entre Cerrado e Mata Atlântica no sudeste do Brasil}

\section{Resumo}

A comunidade de abelhas-das-orquídeas (Hymenoptera: Apidae: Euglossina) foi estudada em uma área de transição entre o Cerrado e a Mata Atlântica, de março de 2010 a fevereiro de 2011, na região de Barroso, estado de Minas Gerais, sudeste do Brasil. Foram utilizadas armadilhas aromáticas utilizando-se três tipos de iscas (cineol, eugenol e vanilina) e redes entomológicas para a captura de abelhas em flores. Foram coletados 614 machos de Euglossina nas armadilhas aromáticas, pertencentes a quatro gêneros e quinze espécies, e vinte e cinco espécimes em flores, pertencentes a dois gêneros e três espécies. Eulaema (Apeulaema) nigrita Lepeletier, 1841 foi a espécie mais comum (50\% dos espécimes coletados), seguida por Euglossa (Euglossa) truncata Rebêlo \& Moure, 1996 (28\%). O cineol foi a isca mais atrativa (66,5\% dos machos e 13 espécies), seguido pelo eugenol ( $16 \%$ e 9 espécies) e vanilina (13,5\% e 4 espécies). Eulaema (Apeulaema) marcii Nemésio, 2009 e Eufriesea auriceps (Friese, 1899) foram atraídas por todas as essências, enquanto as espécies de Euglossa foram coletadas somente em armadilhas contendo cineol ou eugenol.

Palavras-chave: Apoidea, Cerrado, Hexapoda, inventário, Mata Atlântica.

\section{Introduction}

The distribution of orchid bees (Hymenoptera: Apidae: Euglossina) is restricted to the Neotropics, occurring from northern Argentina to southern United States (Dodson et al., 1969, Dressler, 1982a; Michener, 2000). They can be found in different biomes, but they are most diverse and abundant in humid forests (Dressler, 1982a; Kimsey, 1982; Ackerman, 1983; Roubik and Hanson, 2004). They comprise more than 200 described species, distributed into five genera (Nemésio and Rasmussen, 2011), two of which are exclusively cleptoparasites (revision in Nemésio and Silveira, 2006a). Peculiar characteristics of orchid bees include metallic colors, long glossa and, in males, metatibiae specialized in collecting and storing aromatic substances (Dressler, 1982a). These insects are able to fly long distances in search for resources, making them key pollinators in Neotropical ecosystems (Janzen, 1971). 
Orchid-bee males collect aromatic substances produced by certain plant families, especially Orchidaceae, but also some species of Amaryllidaceae, Araceae, Gesneriaceae, Apocynaceae, Solanaceae, Bignoniaceae, Euphorbiaceae, Haemodoraceae, Iridaceae and Theaceae (Dressler, 1982a; Ramírez et al., 2002). The function of these compounds in their biology is still little known (Eltz et al., 1999), though some authors have related them to reproductive activity (Dressler, 1982a; Peruquetti et al., 1999; Silveira et al., 2002).

The collection of information on the relationships between orchid-bee males and the several different species of Orchidaceae led to the discovery of a series of organic compounds that are highly attractive to these bees (Vogel, 1966; Dodson et al., 1969). After the chemical synthesis of these substances as "baits", assessment studies have been carried out on males of these species in order to obtain data on: diversity and abundance (e.g. Nemésio and Silveira, 2006b, 2007a, 2010), stratification (e.g. Oliveira and Campos, 1996; Martins and Souza, 2005), period of activity (e.g. Santos and Sofia, 2002), fragmentation effect (e.g. Powell and Powell, 1987; Tonhasca et al., 2002, 2003; Sofia and Suzuki, 2004), taxonomic studies (e.g. Dressler, 1982b, c, d; Kimsey, 1982; Nemésio, 2007, 2009, 2010a) and biogeographic distribution (e.g. Nemésio and Silveira, 2007b; Rasmussen, 2009; Nemésio, 2010a, b, 2011a, b, 2013a-d; Nemésio and Vasconcelos, 2013).

Although some studies have been carried out in the state of Minas Gerais in areas of Cerrado (Nemésio and Faria Jr., 2004; Alvarenga et al., 2007), Atlantic Forest (Peruquetti et al., 1999; Nemésio, 2003; Nemésio and Silveira, 2006b) and in remnants of semideciduous vegetation (Nemésio and Silveira, 2007a, 2010; Nemésio, 2008), the knowledge on this group is still incipient in many areas of Minas Gerais, particularly its southern portion.

As such, the main goal of the present study was to inventory for the first time the orchid-bee community in transition areas between the Cerrado and Atlantic Forest biomes in the Campo das Vertentes region, state of Minas Gerais, Brazil, in order to provide information on the geographic distribution of orchid bees at the area.

\section{Material and Methods}

\subsection{Study area}

The research was carried out in transition areas between the Cerrado and Atlantic Forest in the region known as Mata do Baú $\left(21^{\circ} 12^{\prime} 24^{\prime \prime}\right.$ S; $\left.43^{\circ} 55^{\prime} 44^{\prime \prime} \mathrm{W}\right)$, a 400 -ha private area, located in the municipality of Barroso, state of Minas Gerais, Brazil. This region is located in an area featuring semideciduous seasonal forest, riparian vegetation and savanna-like fields, which are undergoing anthropic interventions related to economic cycles of mining, agriculture, cattle raising, industry, and in the past were affected by logging in order to feed lime kilns (Menini-Neto et al., 2004; Souza, 2006). The climate in the region is classified as $\mathrm{Cwb}$ - mesothermic with welldefined seasons (Oliveira-Filho and Machado, 1993). The mean annual temperature ranges from $13.1{ }^{\circ} \mathrm{C}$ to $23.7^{\circ} \mathrm{C}$; mean annual rainfall is $1,390 \mathrm{~mm}$, varying from $800 \mathrm{~mm}$ to $1,900 \mathrm{~mm}$. Elevations range from $900 \mathrm{~m}$ (Rio das Mortes) to 1,200 $\mathrm{m}$ above sea level (Morro Boa Vista) (Menini-Neto et al., 2004).

\subsection{Sampling}

The collections of orchid-bee males were carried out using traps, according to the method described by Campos et al. (1989) with changes proposed by Morgado (2006). The compounds used to attract orchid-bee males were: cineole, eugenol and vanillin. These scents have been cited as efficient in collecting orchid-bee males in Minas Gerais (Peruquetti et al., 1999; Nemésio and Faria Jr., 2004; Alvarenga et al., 2007). Samplings were carried out every other week, from March, 2010 to February, 2011, from 09:00 h to 16:00 h, totaling a sampling effort of 168 collection hours per trap.

Nine traps were used, with three replications for each aromatic compound, arranged linearly and interspersed, eight meters from one another, and fixed in the vegetation about two meters above the soil. The baits were inspected every hour, when the trapped bees were removed and the scents were refilled. Collected bees were killed in ethyl acetate and pinned for posterior identification, and deposited in the Laboratório de Taxonomia de Abelhas, Universidade Federal de Uberlândia (UFU).

Concomitantly to the collections using aromatic traps, orchid bees were sampled in the field, using entomological nets, in accordance with the methodology described by Sakagami et al. (1967), which basically consists of capturing bees on flowers or in flight, but with some modifications with regard to time (from four to seven hours) and the interval between each collection (from weekly to every other week).

\subsection{Data analysis}

In order to calculate the total diversity of the study area and between aromatic compounds, the ShannonWiener index (H') was calculated (Magurran, 2004). In order to better interpret the results of the diversity index, the equitability index (J') was used as well (Pieolu, 1975). The comparison of the orchid-bee fauna collected in Minas Gerais state was done by grouping analysis (UPGMA) using the Bray-Curtis distance coefficient.

Only species identified to species level were used in the similarity analysis. Species listed only as "sp." in Nemésio and Silveira (2006b, 2007a) and in the present study were not included in the analysis. Peruquetti et al. (1999) sampled two different areas, the region of Viçosa and the Parque Estadual do Rio Doce (PERD). Nevertheless, Nemésio and Silveira (2006b) carried out a more extensive orchid-bee sampling in the latter area some years later and we here used the data from Nemésio and Silveira (2006b) for PERD. Thus, only the data for Viçosa were here used from Peruquetti et al. (1999). All the sites 
used in the current analysis are indicated in the captions of Figure 1.

\subsection{Taxonomy}

Taxonomy follows Nemésio and Rasmussen (2011). Species listed as Eulaema cingulata (Fabricius, 1804), Euglossa (Euglossa) cordata (Linnaeus, 1758) and Euglossa townsendi Cockerell, 1904 in previous studies in Minas Gerais are here treated as Eulaema (Apeulaema) marcii Nemésio, 2009, Euglossa (Euglossa) carolina Nemésio, 2009 and Euglossa (Euglossa) aratingae Nemésio, 2009, respectively, following Nemésio (2009) and Nemésio and Rasmussen (2011).

\section{Results}

A total of 639 specimens belonging to 15 species in four genera (Table 1) were collected, 614 of them attracted to chemical bait traps, and 25 on flowers (Table 1). Cineole attracted the largest number of individuals and species ( 429 specimens and 13 species), followed by eugenol (104 specimens and nine species) and vanillin (87 specimens and four species). Eulaema marcii and Eufriesea auriceps were attracted by all three compounds, whereas Euglossa species were collected only in cineole and eugenol (Table 1).

Eulaema nigrita was the most abundant species (50.5\% of the specimens), followed by Eg. truncata $(28 \%)$. The remaining species combined accounted for only $21.5 \%$ of the collected specimens. Twenty-five female specimens were actively collected on flowers. Sixteen of them belonged to El. nigrita, eight to Euglossa sp., and one specimen belonged to El. seabrai Moure, 1960.

The diversity and equitability indices, in both collection methods - traps and entomological nets - were $H^{\prime}=1.54$ and $\mathbf{J}=0.57$. However, considering only collections using traps, the indices obtained were $\mathrm{H}^{\prime}=1.48$

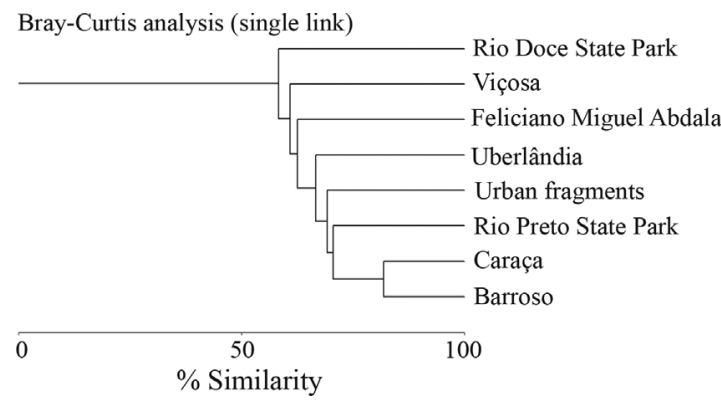

Figure 1 - Similarity among the faunas of orchid-bee males from eight studied areas in Minas Gerais, eastern Brazil. Data retrieved from the regions of Viçosa (Peruquetti et al., 1999), "RPPN Feliciano Miguel Abdala" (Nemésio, 2003), Rio Preto State Park (Nemésio and Faria Jr., 2004), Rio Doce State Park (Nemésio and Silveira, 2006b), Uberlândia (Alvarenga et al., 2007), urban fragments in Belo Horizonte (Nemésio and Silveira, 2007a), Serra do Caraça (Nemésio, 2008) and Barroso (this study). and $\mathrm{J}=0.58$, respectively. Among the compounds used, the highest $H^{\prime}$ value was obtained for cineole $\left(H^{\prime}=1.34\right)$ and the lowest for vanillin $\left(\mathrm{H}^{\prime}=0.84\right)$. With regard to equitability, the highest value was recorded for vanillin $(\mathrm{J}=0.60)$ and the lowest for cineole $(\mathrm{J}=0.52)$.

Based on the similarity analysis among the orchidbee faunas of different assessments carried out in Minas Gerais, it was possible to observe the formation of two groups - one formed by the region of 'Parque Estadual do Rio Doce' (Nemésio and Silveira, 2006b), and another one by the other areas (Figure 1). The greatest similarity was observed in the composition of species in Barroso (this study) and Caraça (Nemésio, 2008), with nearly $82 \%$ similarity (Figure 1).

\section{Discussion}

The composition of the orchid-bee community in transitional forest areas in the municipality of Barroso is similar to other assessments of orchid bees in the Neotropical region, with most species represented by low numbers of individuals, whereas few species are dominant (Oliveira and Campos, 1995; Rebêlo and Garófalo, 1997; Nemésio and Faria Jr., 2004; Sofia et al., 2004; Nemésio and Silveira, 2006, 2007a; Alvarenga et al., 2007; Aguiar and Gaglianone, 2008; Silveira et al., 2011), with prevalence of species with wide distribution in the Atlantic Forest (Nemésio, 2009). All species here collected were listed by Nemésio (2009) in areas regarded as Atlantic Forest in the state of Minas Gerais.

Orchid-bee richness in this work was higher using aromatic traps, when compared to other assessments performed in Brazil (Rebêlo and Garófalo, 1997; Santos and Sofia, 2002; Nemésio, 2003; Sofia et al., 2004; Nemésio and Faria Jr., 2004; Martins and Souza, 2005; Alvarenga et al., 2007; Farias et al., 2008). Nevertheless, this comparison must be analyzed with caution, as any variation in sample effort, collector skills and the very local floristic structure can be significant with regard to richness and diversity of collected species (Nemésio, 2012).

Eulaema nigrita, a widely distributed species, was the most abundant in this study, as in other studies in the Atlantic Forest and Cerrado domains (Neves and Viana, 1997; Peruquetti et al., 1999; Bezerra and Martins, 2001; Tonhasca et al., 2002, Alvarenga et al., 2007; Nemésio and Silveira, 2007a). According to Morato (1998), Tonhasca Jr. et al. (2002) and Nemésio and Silveira, 2006b), this species can be considered a bioindicator of disturbed areas (contra Bezerra and Martins, 2001). If this hypothesis is correct, our data show that the sampled areas should be considered as open or disturbed areas, at least concerning orchid-bee preferences. The group CaraçaBarroso (see Figure 1) was then successively grouped to other areas characterized by open vegetation (Cerrado) or smaller forest remnants. The large Parque Estadual do Rio Doce $(36,000$ ha) shared only about $53 \%$ similarity with all the remaining areas, reinforcing its distinctness within the orchid-bee fauna of Minas Gerais (see Nemésio and Silveira, 2006b). 
Table 1 - List of Euglossini species captured with eugenol (Eu), cineole (Ci), vanillin (Va) and on flowers (Fl) from February, 2010 to March, 2011 at Mata do Baú, Barroso, Minas Gerais.

\begin{tabular}{lccccc}
\hline Species & Eu & Ci & Va & Fl & Total \\
\hline Eufriesea auriceps (Friese, 1899) & 4 & 8 & 7 & - & 19 \\
Eufriesea dentilabris (Mocsáry, 1896) & - & 1 & - & - & 1 \\
Eufriesea violacea (Blanchard, 1840) & - & 13 & 6 & - & 19 \\
Euglossa (Euglossa) aratingae Nemésio, 2009 & - & 5 & - & - & 5 \\
Euglossa (Euglossa) carolina Nemésio, 2009 & 3 & 2 & - & - & 5 \\
Euglossa (Euglossa) fimbriata Moure, 1968 & 5 & 8 & - & - & 13 \\
Euglossa (Euglossa) leucotricha Rebêlo \& Moure, 1996 & 3 & 1 & - & - & 4 \\
Euglossa (Euglossa) securigera Dressler, 1982d & 6 & 3 & - & - & 9 \\
Euglossa (Euglossa) truncata Rebêlo \& Moure, 1996 & 67 & 112 & - & - & 179 \\
Euglossa sp. (female) & - & - & - & 8 & 8 \\
Euglossa (Glossura) stellfeldi Moure, 1947 & 7 & 11 & - & - & 18 \\
Eulaema (Eulaema) seabrai Moure, 1960 & - & - & - & 1 & 1 \\
Eulaema (Apeulaema) marcii Nemésio, 2009 & 1 & 17 & 9 & - & 27 \\
Eulaema (Apeulaema) nigrita Lepeletier, 1841 & - & 242 & 65 & 16 & 323 \\
Exaerete smaragdina (Guérin-Méneville, 1844) & 3 & 5 & - & - & 8 \\
Total individuals & 99 & 428 & 87 & 25 & 639 \\
Total species & 9 & 13 & 4 & 3 & 15 \\
\hline
\end{tabular}

Cineole was the most attractive compound; this result corroborates those found by almost all previous authors (Ackerman, 1983; Rebêlo and Garófalo, 1991; Morato et al., 1992; Rebêlo and Cabral, 1997; Rebêlo and Garófalo, 1997; Alvarenga et al., 2007; Mendes et al., 2008; Storck-Tonon et al., 2009), reinforcing the importance of its use in orchid-bee inventories. Although the use of aromatic compounds to collect orchid bees proved to be efficient in several studies, the use of more than one sampling method, such as active flower search or nest traps can increase sampling efficiency, as data obtained through one method can complement those obtained through another (Rebêlo and Garófalo, 1997; Nemésio, 2012).

It is important to highlight the record in this study of a female specimen of Eulaema seabrai captured on flower, representing the second record of that species in Minas Gerais (see Nemésio and Silveira, 2004) and reinforcing the importance of multiple sampling methods to better inventory orchid-bee faunas.

The similarity among areas reflects the relative abundances of their shared species. The highest similarity values were found in the semideciduous forest areas at 'Serra do Caraça' (Nemésio, 2008) and the region between the Cerrado and Atlantic Forest (present study), with $82 \%$ of similarity. This can be explained by the somewhat similar vegetation structure of both areas, or even by the geographical proximity between them, as well as historical and biogeographic factors. According to Bezerra and Martins (2001), it is expected that orchid-bee communities are similar in neighboring geo- graphic regions, with similar climate, vegetation and topography.

Although the use of traps proved efficient in attracting orchid-bee males, the limitation of this method should be emphasized when compared to active collection with entomological nets. Nemésio and Morato (2004, 2006), during studies in the Amazon region, demonstrated that there could be a bias in collections using traps, as specimens of smaller species (particularly of Euglossa spp.) tend to escape more easily than larger bees, resulting in a higher rate of specimens of Eulaema spp. Recently, Mattozo et al. (2011) confirmed Nemésio and Morato's $(2004,2006)$ hypothesis in areas of Atlantic Forest. Future studies adding other aromatic compounds and methodology variations may contribute to better detail our understanding of the diversity of orchid bees in the region.

\section{Acknowledgments}

We thank FAPEMIG for financial support (Programa Biota Minas, edital 14/2009); IBAMA for collecting license and family Melo, owners of "Mata do Baú", for allowing the studies at their area.

\section{References}

ACKERMAN, JD., 1983. Diversity and seasonality of male euglossine bees (Hymenoptera: Apidae) in central Panama. Ecology, vol. 64, p. 274-283.

ALVARENGA, PEF., FREITAS, RF. and AUGUSTO, SC., 2007. Diversidade de Euglossini (Hymenoptera: Apidae) 
em áreas de Cerrado do Triângulo Mineiro, MG. Bioscience Journal, vol. 23, p. 30-37.

AGUIAR, WM. and GAGLIANONE, MC., 2008. Comunidade de Abelhas Euglossina (Hymenoptera: Apidae) em Remanescentes de Mata Estacional Semidecidual sobre Tabuleiro no Estado do Rio de Janeiro. Neotropical Entomology, vol. 37, p. 118-125.

BEZERRA, CP. and MARTINS, CF., 2001. Diversidade de Euglossinae (Hymenoptera; Apidae) em dois fragmentos de Mata Atlântica localizados na região urbana de João Pessoa, Paraíba, Brasil. Revista Brasileira de Zoologia, vol. 18, p. 823-825.

BLANCHARD, C.É., 1840. Hyménoptères. In LAPORTE DE CASTELNAU, FLN. (Ed.). Histoire naturelle des insectes. Orthoptères, Névroptères, Hemiptères, Hyménoptères, Lepidoptères et Diptères. Paris: Duméril. vol. 3. p. 219-415.

CAMPOS, LAO., SILVEIRA, FA., OLIVEIRA, ML., ABRANTES, CMV., MORATO, EF. and MELO, GAR., 1989. Utilização de armadilhas para a captura de machos de Euglossini (Hymenoptera, Apoidea). Revista Brasileira de Zoologia, vol. 6, p. 621-626.

COCKERELL, TDA., 1904. Descriptions and records of bees Annals and Magazine of Natural History, vol. 7, n. 14, p. 21-30.

DODSON, CH., DRESSLER, RL., HILLS, HG., ADAMS, RM. and WILLIAMS, NH., 1969. Biologically active compounds in orchid fragrances. Science, vol. 164, p. 12431249.

DRESSLER, RL., 1982a. Biology of the orchid bees (Euglossini). Annual Review of Ecology and Systematics, vol. 13, p. 373-394.

DRESSLER, RL., 1982b. New species of Euglossa II. (Hymenoptera: Apidae). Revista de Biologia Tropical, vol. 30, p. 121-129.

DRESSLER, RL., 1982c. New species of Euglossa. III. The bursigera species group (Hymenoptera: Apidae). Revista de Biologia Tropical, vol. 30, p. 131-140.

DRESSLER, RL., 1982d. New species of Euglossa IV. The cordata and purpurea species groups. Revista de Biologia Tropical, vol. 30, p. 141-150.

ELTZ, T., WHITTEN, WM., ROUBIK, DW. and LINSENMAIR, KE., 1999. Fragrance collection, storage, and accumulation by individual male orchid bees. Journal of Chemical Ecology, vol. 25, p. 157-176.

FARIAS, RCAP., MADEIRA-DA-SILVA, MC., PEREIRAPEIXOTO, MH. and MARTINS, CF., 2008. Composição e Sazonalidade de Espécies de Euglossina (Hymenoptera: Apidae) em Mata e Duna na Área de Proteção Ambiental da Barra do Rio Mamanguape, Rio Tinto, PB. Neotropical Entomology, vol. 37, p. 253-258.

FRIESE, H., 1899. Monographie der Bienengattung Euglossa Latr. Természetrajzi Füzetek, vol. 22, p. 117-172.

GUÉRIN-MENÉVILLE, FE., 1844. Iconographie du règne animal de G. Cuvier, ou représentation d'après nature de l'une des espèces les plus remarquables, et souvent non encore figurées, de chaque genre d'animaux. Avec un texte descriptif mis au courant de la science. Ouvrage pouvant servir d'atlas a tous les traités de zoologie. Paris: J.B. Baillière. $576 \mathrm{p}$.

JANZEN, DH., 1971. Euglossine bees as long-distance pollinators of tropical plants. Science, vol. 171, p. 203-205.
KIMSEY, LS., 1982. Systematics of bees of the genus Eufriesea. University of California Publications in Entomology, vol. 95, p. 1-125.

LEPELETIER DE SAINT FARGEAU, ALM., 1841. Histoire Naturelle des Insectes, Hyménoptères, Vol. 2. Paris: Librairie Encyclopédique de Roret. 680 p.

LINNAEUS, C., 1758. Systema Naturae per Regna tria Naturae, secundum Classes, Ordines, Genera, Species, cum Charateri-bus, Differentiis, Synonymis, Locis. Tomus I. Editio Decima Reformata. Stockholm: Laurentii Salvii. $823 \mathrm{p}$.

MARTINS, CF. and SOUZA, AKP., 2005. Estratificação vertical de abelhas Euglossina (Hymenoptera, Apidae) em uma área de Mata Atlântica, Paraíba, Brasil. Revista Brasileira de Zoologia, vol. 22, p. 913-918.

MATTOZO, VC., FARIA, LRR. and MELO, GAR., 2011. Orchid bees (Hymenoptera: Apidae) in the coastal forests of southern Brazil: diversity, efficiency of sampling methods and comparison with other Atlantic Forest surveys. Papéis Avulsos de Zoologia, vol. 51, p. 505-515.

MENDES, FN., RÊGO, MMC. and CARVALHO, CC., 2008. Abelhas Euglossina (Hymenoptera, Apidae) coletadas em uma monocultura de eucalipto circundada por Cerrado em Urbano Santos, Maranhão, Brasil. Iheringia, vol. 98, p. $285-290$.

MENINI-NETO, L., ASSIS, LC. and FORZZA, RF., 2004. A família Orchidaceae em um fragmento de floresta estacional semidecidual, no município de Barroso, Minas Gerais, Brasil. Lundiana, vol. 4, p. 9-27.

MICHENER, CD., 2000. The bees of the world. The Johns Hopkins University Press, Baltimore, 913 p.

MOCSÁRY, A., 1896. Species Hymenopterorum magnificæ novæ in collectione musæi nationalis Hungarici. Természetrajzi Füzetek, vol. 19, p. 1-8.

MORGADO, LN., 2006. Biologia floral, fenologia reprodutiva e guilda de abelhas (Hymenoptera: Apoidea) visitantes florais de quatro espécies de Tillandsia L. (Bromeliaceae: Tillandsioideae) na Ilha Grande, Estado do Rio de Janeiro, Brasil. Rio de Janeiro: Universidade Estadual do Rio de Janeiro. 143p. Tese de Doutorado.

MORATO, EF., 1998. Estudos sobre comunidades de abelhas Euglossini. Anais do Encontro sobre Abelhas, vol. 3, p. 135-143.

MORATO, EF., CAMPOS, LAO. and MOURE, JS., 1992. Abelhas Euglossini (Hymenoptera, Apidae) coletadas na Amazônia Central. Revista Brasileira de Entomologia, vol. 36, p. 767-771.

MOURE, JS., 1947. Novos agrupamentos genéricos e algumas espécies novas de abelhas sulamericanas. Publicações Avulsas, Museu Paranaense, vol. 3, p. 1-37.

-, 1960. Notes on the types of the neotropical bees described by Fabricius (Hymenoptera: Apoidea). Studia Entomologica, vol. 3, p. 97-160

-, 1968. Espécies novas de Euglossa da América Central (Hymenoptera, Apidae). Boletim da Universidade Federal do Paraná, Zoologia, vol. 3, p. 13-64.

NEMÉSIO, A., 2003. Preliminary sampling of Euglossina (Hymenoptera: Apidae: Apini) of Reserva Particular do Patrimônio Natural Feliciano Miguel Abdala, Caratinga, Minas Gerais state, Brazil. Lundiana, vol. 4, p. 121-124.

-, 2007. Three new species of Euglossa Latreille (Hymenoptera: Apidae) from Brazil. Zootaxa, vol. 1547, p. 21-31. 
-, 2008. Orchid bee community (Hymenoptera, Apidae) at an altitudinal gradient in a large forest fragment in southeastern Brazil. Revista Brasileira de Zoociências, vol. 10, p. 251-258.

-, 2009. Orchid bees (Hymenoptera: Apidae) of the Brazilian Atlantic Forest. Zootaxa, vol. 2041, p. 1-242.

-, 2010a. Eulaema (Apeulaema) felipei sp. n. (Hymenoptera: Apidae: Euglossina): a new forest-dependent orchid bee found at the brink of extinction in northeastern Brazil. Zootaxa, vol. 2424, p. 51-62.

-, 2010b. The orchid-bee fauna (Hymenoptera: Apidae) of a forest remnant in northeastern Brazil, with new geographic records and an identification key to the known species of the Atlantic Forest of northeastern Brazil. Zootaxa, vol. 2656, p. 55-66.

-, 2011a. The orchid-bee fauna (Hymenoptera: Apidae) of a forest remnant in southern Bahia, Brazil, with new geographic records and an identification key to the known species of the area. Zootaxa, vol. 2821, p. 47-54.

-, 2011b. Euglossa marianae sp. n. (Hymenoptera: Apidae): a new orchid bee from the Brazilian Atlantic Forest and the possible first documented local extinction of a forest dependent orchid bee. Zootaxa, vol. 2892, p. 59-68.

-, 2011c. Exaerete salsai sp. n. (Hymenoptera: Apidae): a new orchid bee from eastern Brazil. Zootaxa, vol. 2967, p. 12-20.

-, 2011d. Euglossa bembei sp. n. (Hymenoptera: Apidae): a new orchid bee from the Brazilian Atlantic Forest belonging to the Euglossa cybelia Moure, 1968 species group. Zootaxa, vol. 3006, p. 43-49.

-, 2012. Methodological concerns and challenges in ecological studies with orchid bees (Hymenoptera: Apidae: Euglossina). Bioscience Journal, vol. 28, p. 118-134.

-, 2013a. The orchid-bee fauna (Hymenoptera: Apidae) of 'Reserva Biológica de Una', a hotspot in the Atlantic Forest of southern Bahia, eastern Brazil. Brazilian Journal of Biology, vol. 73, n. 2, p. 347-352.

-, 2013b. Are orchid bees at risk? First comparative survey suggests declining populations of forest-dependent species. Brazilian Journal of Biology, vol. 73, n. 2, p. 367-374.

-, 2013c. The orchid-bee faunas (Hymenoptera: Apidae) of two Atlantic Forest remnants in southern Bahia, eastern Brazil. Brazilian Journal of Biology, vol. 73, n. 2, p. 375-381.

-, 2013d. The orchid-bee faunas (Hymenoptera: Apidae) of 'Parque Nacional do Monte Pascoal', 'Parque Nacional do Descobrimento' and three other Atlantic Forest remnants in southern Bahia, eastern Brazil. Brazilian Journal of Biology, vol. 73, n. 2, p. 437-446.

NEMÉSIO, A. and FARIA Jr., LRR., 2004. First assessment of orchid bee fauna (Hymenoptera: Apidae: Apini: Euglossina) of Parque Estadual do Rio Preto, a cerrado area in southeastern Brazil. Lundiana, vol. 5, p. 113-117.

NEMÉSIO, A. and MORATO, EF., 2004. Euglossina (Hymenoptera: Apidae: Apini) of the Humaitá Reserve, Acre state, Brazilian Amazon, with comment on bait trap efficiency. Revista de Tecnologia e Ambiente, vol. 10, p. $71-80$.

-, 2006. The orchid-bee fauna (Hymenoptera: Apidae) of Acre state (northwestern Brazil) and a re-evaluation of euglossine bait-trapping. Lundiana, vol. 7, p. 59-64.

NEMÉSIO, A. and RASMUSSEN, C., 2011. Taxonomic issues in the orchid bees (Hymenoptera: Apidae: Euglossina), and an updated catalogue. Zootaxa, vol. 3006, p. 1-42.
NEMESIO, A. and SILVEIRA, FA., 2004. Biogeographic notes on rare species of Euglossina (Hymenoptera: Apidae: Apini) occurring in the Brazilian Atlantic Rain Forest. Neotropical Entomology, vol. 33, p. 117-120.

-, 2006a. Deriving ecological relationships from geographic correlations between host and parasitic species - an example with orchid bees. Journal of Biogeography, vol. 33, p. 91-97.

-, 2006b. Edge effects on the orchid-bee fauna (Hymenoptera: Apidae) at a large remnant of Atlantic Forest in southeastern Brazil. Neotropical Entomology, vol. 35, p. 313-323.

-, 2007a. Orchid bee fauna (Hymenoptera: Apidae: Euglossina) of Atlantic Forest fragments inside an urban area in southeastern Brazil. Neotropical Entomology, vol. 36, p. 186-191.

-, 2007b. Diversity and distribution of orchid bees (Hymenoptera: Apidae: Euglossina) with a revised checklist of their species. Neotropical Entomology, v ol. 36, p. 874888.

-, 2010. Forest fragments with larger core areas better sustain diverse orchid bee faunas (Hymenoptera: Apidae: Euglossina). Neotropical Entomology, vol. 39, p. 555-561.

NEMÉSIO, A. and VASCONCELOS, HL. 2013. Beta diversity of orchid bees in a tropical biodiversity hotspot. Biodiversity and Conservation, vol. 22, p. 1647-1661.

NEVES, EL. and VIANA, BF., 1997. Inventário da fauna de Euglossinae (Hymenoptera, Apidae) do baixo sul da Bahia, Brasil. Revista Brasileira de Zoologia vol. 14, p. $831-837$.

OLIVEIRA-FILHO, AT. and MACHADO, JMN., 1993. Composição florística de uma floresta semidecídua montana na Serra de São José, Tiradentes, Minas Gerais. Acta Botanica Brasílica, vol. 7, p. 71-88.

OLIVEIRA, ML. and CAMPOS, LAO., 1995. Abundância, riqueza e diversidade de abelhas Euglossinae (Hymenoptera: Apidae) em florestas contínuas de terra firme na Amazônia Central, Brasil. Revista Brasileira de Zoologia, vol. 12, p. 547-556.

PERUQUETTI, RC., CAMPOS, LAO., COELHO, CD., ABRANTES, CVM. and LISBOA, LCO., 1999. Abelhas Euglossini (Apidae) de áreas de Mata Atlântica: abundância, riqueza e aspectos biológicos. Revista Brasileira de Zoologia, vol. 16 (Suppl. 1), p. 101-118.

POWELL, AH. and POWELL, GVN., 1987. Population dynamics of male euglossine bees in Amazonian forest fragments. Biotropica, vol. 19 ,p. 176-179.

RAMÍREZ, S., DRESSLER, R. and OSPINA, M., 2002. Abejas euglosinas (Hymenoptera: Apidae) de la Región Neotropical: Listado de especies con notas sobre su biología. Biota Colombiana, vol. 3, p. 7-118.

RASMUSSEN, C., 2009. Diversity and abundance of orchid bees (Hymenoptea: Apidae, Euglossini) in a tropical rainforest succession. Neotropical Entomology, vol. 38, p. 66-73.

REBÊLO, JMM. and CABRAL, AJ., 1997. Abelhas Euglossinae de Barreirinhas, zona do litoral da Baixada Oriental Maranhense. Acta Amazonica, vol. 27, p. 145-152.

REBÊLO, JMM. and GARóFALO, CA., 1991. Diversidade e sazonalidade de machos de Euglossini (Hymenoptera, Apidae) e preferência por iscas odores em um fragmento de floresta no sudeste do Brasil. Revista Brasileira de Biologia, vol. 51, p. 787-799. 
-, 1997. Comunidades de machos de Euglossinae (Hymenoptera, Apidae) em matas semidecíduas do nordeste do estado de São Paulo. Anais da Sociedade Entomológica do Brasil, vol. 26, p. 243-256.

REBÊLO, JMM. and MOURE, JS., 1996. [1995] As espécies de Euglossa Latreille do nordeste de São Paulo (Apidae, Euglossinae). Revista Brasileira de Zoologia, vol. 12, p. 445-466.

ROUBIK, DW. and HANSON, PE., 2004. Orchid bees of tropical America: biology and field guide. INBIO, San Jose, $370 \mathrm{pp}$.

SANTOS, AM. and SOFIA, SH., 2002. Horário de atividade de machos de Euglossinae (Hymenoptera, Apidae) em um fragmento de floresta semidecídua no norte do estado do Paraná. Acta Scientiarum, vol. 24, p. 375-381.

SILVEIRA, FA., MELO, GAR. and ALMEIDA, EAB., 2002. Abelhas brasileiras: sistemática e identificação. F.A. Silveira, Belo Horizonte, 252 pp.

SILVEIRA, GC., NASCIMENTO, AM., SOFIA, SH. and AUGUSTO, SC., 2011. Diversity of the euglossine bee community (Hymenoptera, Apidae) of an Atlantic Forest remnant in southeastern Brazil. Revista Brasileira de Entomologia, vol. 55, p. 109-115.
SOFIA, SH., SANTOS, AM. and SILVA, CRM., 2004. Euglossine bees (Hymenoptera, apidae) in a remnant of atlantic Forest in Paraná State, Brazil. Iheringia, vol. 94, p. $217-$ 222.

SOFIA, SH. and SUZUKI, KM., 2004. Comunidades de Machos de Abelhas Euglossina (Hymenoptera: Apidae) em Fragmentos Florestais no Sul do Brasil. Neotropical Entomology, vol. 33, p. 693-702.

SOUZA, MM., 2006. Barroso, uma história de desmatamentos e de esforços atuais para conservação. Vertentes, vol. 27, p. 16-26.

STORCK-TONON, D., MORATO, EF. and OLIVEIRA, ML., 2009. Fauna de Euglossina (Hymenoptera: Apidae) da Amazônia Sul-Ocidental, Acre, Brasil. Acta Amazonica, vol. 39, p. 693-706.

TONHASCA Jr., A., BLACKMER, JL. AND ALBUQUERQUE, GS., 2002. Abundance and diversity of euglossine bees in the fragmented landscape of the Brazilian Atlantic Forest. Biotropica, vol. 34, p. 416-422.

VOGEL, S. 1966. Parfümsammelnde Bienen als Bestäuber von Orchidaceen und Gloxinia. Österreichische botanische Zeitschrift, vol. 113, p. 302-361. 